\title{
Genetics and inflammatory profile in tobacco dependence
}

Corina Eugenia Budin ${ }^{1,2}$, Ruxandra Rajnoveanu1, loana Roxana Bordea ${ }^{3, *}$, Corina Marginean², Bianca Domokos ${ }^{1}$, Elena Dantes ${ }^{5}$, Doina Adina Todea ${ }^{1}$

'Department of Pneumology, University of Medicine and Pharmacy "Iuliu Hatieganu" Cluj Napoca, Romania

${ }^{2}$ Clinical County Hospital Targu Mures, Pneumology, Romania

${ }^{3}$ Department of Oral Rehabilitation, Iuliu Hateganu University of Medicine and Pharmacy, Oral Health and Dental Office Management,

Cluj Napoca, Romania

${ }^{4}$ Clinical County Hospital, Pneumology, Targu Mures, Romania

Abstract

${ }^{5}$ Department of Pneumology, Faculty of Medicine, "Ovidius" University Constanta, Constanţa, Romania

English:

The state of health of the population is determined by a set of factors belonging to human biology, environment, behaviors, and the health system (preventive, curative, and rehabilitative). Any of these factors can alter both individual and community health.

The primary reason for tobacco dependence is nicotine addiction. Dopamine is released from the neurons located in the mesolimbic system. Nicotine stimulates the release of dopamine from these receptors. The genetic determination of nicotine dependence is determined by the subtypes of nicotine acetylcholine receptors (nAChRs) and conditioned by chromosome mutations at chromosomes $15 q 25.1,8 p 11.21$ or 20q13.12-q13.32.

Low-amplitude systemic inflammation is demonstrated in all smokers and is confirmed by elevated levels of C-reactive protein, fibrinogen, Interleukin-6, and increased leukocyte levels. Moreover, coagulation and endothelial function markers such as hematocrit, plasma or blood viscosity, D-dimers, circulating adhesion molecules, tissue plasminogen activator, have also modified values in smokers.

Keywords

smoking $\bullet$ nicotine dependence $\cdot$ genetics $\bullet$ inflammation

\section{Genetica si profilul inflamator al dependentei tabagice}

Rezumat

Romanian:

Starea de sanatate a unei populatii este influentata de o serie de factori: biologici, factori de mediu si comportamentali, precum si de nivelul sistemului sanitar. Oricare dintre acestia poate influenta starea de sanatate individuala sau a comunitatii.

Principala cauza a dependentei tabagice este adictia la nicotina. Dopamina este eliberata din neuronii localizati in sistemul mezolimbic. Nicotina stimuleaza eliberarea dopaminei din acesti receptori. Determinismul genetic al adictiei de nicotina este determinata de subtipurile receptorilor nicotinici acetilcolinici ( $n A C h R s$ ) si conditionata de mutatiile cromozomiale 15q25.1, 8p11.21 sau 20q13.12-q13.32.

O inflamatie sistemica de amplitudine scazuta este demonstrata la toti fumatorii si confirmata de valori crescute ale nivelului de leucocite, proteinei C reactive, fibrinogen, interleukina 6 . De asemenea, alti parametri: hematocrit, vascozitatea plasmatica sau sangvina, D-dimerii, activatorul tisular al plasminogenului pot avea valori modificate la fumatori.

Cuvinte-cheie

fumat $\cdot$ dependenta nicotinica $\bullet$ genetica $\bullet$ inflamatie

${ }^{*}$ Corresponding author: loana Roxana Bordea

E-mail: roxana.bordea@ymail.com, bordea.ioana@umfcluj.ro

Ә Open Access. (c) 2019 Budin et al., published by Sciendo

(r) Br-Nc-ND This work is licensed under the Creative Commons Attribution-NonCommercial-NoDerivs 4.0 License. 


\section{Theoretical background of tobacco addiction}

Tobacco addiction, a topical issue at national and international level, is a chronic disease usually acquired in adolescence, which is why it is considered a priority of public health. All healthcare professionals should consider tobacco consumption (both by inhalation and chewing) as a health issue, even if the patient has not yet developed a tobacco addiction. Since tobacco dependence is a disease, it has to be diagnosed and treated like any chronic illness. A healthcare professional has the duty to intervene and initiate the quitting of smoking. Early initiation of treatment for tobacco addiction is a good practice for doctors and health professionals because tobacco consumption is mainly determined by tobacco dependence. Only in exceptional cases, smoking can be considered as a free choice of lifestyle by the smoker. No treatment or failure to plan treatment for tobacco-addicted patients is a mistake. In any case, clinicians should provide minimal counseling to all patients who consume tobacco (1).

The prevalence of smoking is steadily increasing in the young puberty and adolescence population, so smoking in this age group should be considered a priority of Public Health (2).

Tobacco users who started smoking at adolescence are usually more addicted than those who started when they were adults. Nicotine, a substance with psychoactive properties, creates an acute need for cigarettes, cigars, pipes, making smokers incapable of giving up easily and causing them physical and mental symptoms when they refrain from smoking (2).

\section{Recommendations of World Health Organization}

The state of health of the population is determined by a set of factors belonging to human biology (heredity, complex biological systems, and aging phenomenon of the organism), environment (social, physical, psychic), behaviors (leisure habits, professional risks, habit, food, and consumption) and the health system (preventive, curative, and rehabilitative). Any of these factors can alter both individual and community health.

Although there has been significant progress in the world in the fight against smoking, it remains a challenge to reduce the prevalence and consumption of tobacco among children and adolescents (1).

Prohibiting the sale of tobacco products to minors and increasing prices, warnings on cigarette packs, and providing smoke-free rooms are crucial in preventing smoking in teenagers. Overall, at least 1 in 10 adolescents aged between
13 and 15 years of age smoke, although there are areas where the age is even lower. In developed countries and with sustained educational programs, the incidence of smoking in minors seems to be decreasing (3).

Worldwide, World Health Organization (WHO) reported a smoking prevalence among adolescents of $13,9 \% ; 23,9 \%$ of smokers adolescents started smoking under the age of 10 years. In Europe, the average incidence is $26.87 \%$. In the United States, the average number of teenagers who smoke is $17.7 \%$. In Romania, $23 \%$ of teenagers are smokers. A study conducted in Sweden during a campaign to prevent smoking in adolescents has shown low adherence to enrollment among young mothers and the underprivileged (4).

The WHO recommends the MPOWER strategy to control tobacco:

M - monitoring the epidemic;

$\mathrm{P}$ - protects the health of the nonsmoker from cigarette smoke pollution

$\mathrm{O}$ - offers help to the smoker to quit smoking;

$\mathrm{W}$ - warns the population about the risks associated with tobacco use;

E - It imposes prohibitions on tobacco advertising, promotion, and sponsorship (sponsorship and promotion);

$\mathrm{R}$ - increases taxes on tobacco (2).

Tobacco consumption is the leading cause of premature illness and death in Europe. It is known that a smokers' life expectancy is 10 years shorter than that of a nonsmoker: $50 \%$ of smokers lose 20 years of healthy life before they die of a disease caused by tobacco (5).

The consumption of a cigarette decreases for the moment the desire to smoke, but causes a desensitization of the nicotinic receptors and at the same time, the increase of their number, precipitating the need for the next cigarette (6). This continuous stimulation caused by tobacco consumption leads to chronic consumption (7).

\section{Genetics of nicotine addiction}

The primary reason for this addiction is nicotine dependence. Tobacco dependence is influenced by genetic, environmental factors, and also by behavioral factors. Knowing that parental smoking generates a higher incidence of smoking in children, there has been a hypothesis to show that nicotine action starts at the brain level (7). A study conducted by Picciotto and Mineur in 2014 in the United States highlighted that smoking 
tobacco products triggered one of the strongest addictions in the human race.

\section{Nicotine and neuromediators}

Acute exposures to nicotine determine rapid activation of the prefrontal cortex and thalamus concomitant with corticobasal ganglia activation. Nicotine that stimulates acetylcholine nicotinic receptors causes the release of dopamine, but also of norepinephrine, acetylcholine, gamma-aminobutyric acid (GABA), and endorphins (8).

Dopamine is released from the neurons located in the mesolimbic system. The ability of nicotine to potentiate glutamatergic signals at neuronal level was demonstrated by Mansvelder and McGehee in 2000 and further augmented in 2009 by Tang and Dani in their studies (9). Thus, nicotine, considered a high potency drug, induces a dose-dependent impairment of synaptic terminations related to learning and memory.

Nicotine, however, stimulates both the GABA receptor and the glutamatergic receptors in the hippocampus, an area of the brain considered responsible for addictive addictions $(8,10)$. Another explanation for the effect of nicotine is that it stimulates nicotinic acetylcholine receptors (nAChRs), but equally desensitizes them, as demonstrated by the studies of Grady, Picciotto, and Pidoplichko $(7,10)$. Repeated exposure to nicotine causes desensitization of dopamine-releasing receptors. This mixed response, both sensitization and desensitization, can be explained by the existence of several subtypes of acetylcholine nicotinic receptors, which determines the varied response of each individual to the consumption of tobacco products (11).

\section{Chromosomal mutations}

The results of the latest meta-analyses on smoking in genetics have concluded that the variation of the individual response is generated by the variability of the receptor subtypes (12). The strongest genomic evidence was demonstrated in CHRNA5-CHRNA3-CHRNB4 gene mutation at chromosome $15 q 25.1$, subunits $\alpha 3,4,5$. These mutations of chromosome $15 q 25.1$ were found in the European population, North American, but not in the Asian population $(12,13)$. Other chromosome variations involved in tobacco product response variability cause mutations in chromosomes $8 p 11.21$ (CHRNA6, CHRNB3), 20q13.12-q13.32, a locus containing CHRNA4 (14).

Exposure to smoking during pregnancy or early childhood causes an increase in smoking incidence at older ages. It has not been shown, however, whether this is due to genetic inheritance from parents of the same types of acetylcholine sub-receptors or because of the behavioral loan. Role and Berg demonstrated in 1996 that nAChRs contribute to normal neuronal development, and nicotine can disturb this balance (15). In research studies, used as a medicine, nicotine causes attention to increase, diminishes anxiety and can be used even as an easy analgesic. Repeated exposure at nicotine triggers the phenomenon of tolerance to some of the physiological effects of nicotine and repeated exposure and cumulative doses do not maintain these effects $(9,10)$. This effect can be explained by the desensitization of dopaminergic receptors following their initial stimulation by nicotine $(11,14)$.

The interaction of the environment with genetic determinism is influenced by CHRNA5 mutations and confirmed by the association between nicotine dependence and rs 16969968 . This allele mutation rs 16969968 is responsible for increased addiction in adulthood to those who initiated smoking before 16 years of age. Thus, those who have the present mutation and initiate smoking under the age of 16 have an increased risk of becoming heavy smokers.

Although the genetic risk factor for nicotine addiction is present from birth, the distinct development of smoker/nonsmoker phenotypes and the degree of addiction is also influenced by the environment, which can modify this gene expression. Finnish FinnTwin12 study on twin families has augmented that the importance of smoking genetics in adolescents is decreasing and the importance of the environment is increasing (11-13). Thus, although genetic determinism is not the only triggering factor of nicotine addiction, continuous increasing of morbidity and mortality due to smoking requires a development of all research that can prevent this endemic pathology $(12,16,17)$.

\section{Inflammation caused by smoking}

Chronic exposure in smoking, for a long time, determines an imbalance of oxidant-antioxidant balance, reflected by increased lipid production of peroxidation and lower levels of antioxidants such as vitamin A and C in smokers' plasma. Low amplitude systemic inflammation is demonstrated in all smokers and it is confirmed in adults by elevated levels of C-reactive protein, fibrinogen, Interleukin-6, and increased leukocyte levels. Moreover, coagulation and endothelial function markers such as hematocrit, plasma or blood viscosity, D-dimers, circulating adhesion molecules, tissue plasminogen activator, have also modified values at adult smokers $(17,18)$.

A study developed in Quebec in 1999 demonstrated for the first time the association between elevated levels of $C$ reactive protein and smoker status in adolescents. Moreover, adolescents who declared themselves to be heavy smokers in the last month had even higher values of $\mathrm{C}$ - reactive protein (18). This biomarker was considered the most accurate 
regarding the inflammatory profile in the adolescents and young population.

Although most of the smoking-induced inflammatory changes are reversible after withdrawal, some of the biomarkers, for example, C-reactive protein, still remain at high levels for former smokers for a variable period, sometimes 10-20 years after smoking cessation, suggesting a low but persistent inflammation (18-20).

There is a demonstrated correlation between exposure to cigarette smoke particles and airway sensitization by inflammation, clinically expressed by bronchial hyperreactivity $(21,22)$. The effector cells involved in inflammation in the bronchial tree are neutrophils, macrophages, dendritic cells, and eosinophils (23).

Exposure to secondhand smoking and third-hand smoking has been recognized as a risk factor for adults in the development of bronchopulmonary cancer in nonsmokers (24). This risk can be assessed by the use of specific biomarkers such as 4-(methylnitrosamino)-1-(3-pyridyl)-1butanol and 1-(methylnitrosamino)-1-(3pyridyl) butan-4-(isoNNAL) (25).

The association between smoking and cardiovascular disease is well known. Thus, studies conducted by Libby and Ross in the early 2000s have shown that both cardiovascular disease and atherosclerosis per se have a major inflammatory component $(18,19)$. The association between smoking and cardiovascular pathology in adults has been demonstrated by persistently elevated levels of adult C- reactive protein. In addition, an association between smoking and other chronic inflammatory diseases has been demonstrated, affecting various anatomic organs and systems such as chronic obstructive pulmonary disease, rheumatoid arthritis, systemic lupus erythematosus, or Crohn's disease. Smoking associated with these autoimmune pathologies worsens the progression of the disease and influences the response to treatment. Therefore, the interrelation between inflammatory biomarkers and smoking has become a certain area of interest, correlating smoking with increased rates of morbidity and mortality through various pathologies (26-28).

Although the C- reactive protein appears to be the inflammatory biomarker with the highest correlation with the nicotinic dependence level, there are other inflammatory biomarkers whose value can guide the level of inflammation, such as a tumor necrosis factor a, interleukin 1, 6, 8, $12(29,30)$. However, the level of C-reactive protein may also be influenced by other factors, such as age, body mass index, weight, and condition or deconditioning of the body $(19,20,31)$. At the same time, the level of C-reactive protein is very variable in quantitative terms, with oscillating values after smoking cessation $(29,32,33)$.
In conclusion, smoking and implicitly, nicotine addiction is a chronic disease with a growing morbidity and mortality rate. There are a cumulative number of etiological factors that can influence this addiction, starting from genetic, nonmodifiable factors, and continuing with environmental and behavioral factors that can be prevented or influenced. Therefore, smoking prevention programs should be started from as young as possible, so that even if there is a predisposing genetic factor, it can be counteracted by the additional environmental and behavioral measures.

Smoking-induced inflammation has been certified by specialized literature. Although smoking studies include subjects only from adolescence, smoking in children is a reality that must be tackled with all means. Inflammation associated with smoking has been demonstrated in both adolescents and adults. Extrapolating these data, we can conclude that the inflammatory profile is exacerbated at all ages and all categories of smokers. Depending on the magnitude of inflammation, we can guide the treatment of patients with chronic pathologies.

Also, we do not have to summarize inflammation associated with smoking only to the respiratory pathology, this inflammation being also interconnected with other nonrespiratory inflammatory pathologies. Although some biomarkers, such as C- reactive protein, are generally used to quantify the infection, there are situations, for example at smokers, in which case the biomarkers have the utility to identify and quantify a subclinical inflammation.

The effort to reduce as much as possible the incidence of nicotine addiction in the general population is correlated with the aim of preventing potential chronic inflammatory or noninflammatory pathologies interconnected with smoking.

\section{Ethics approval and consent to participate}

Not applicable.

\section{Competing interests}

The authors declare that they have no competing interests.

\section{References}

1. European Smoking Cessation Guidelines and Quality Standards European Network [Internet]. [cited 2018 May 10]. Available from: http://ensp.org/wp-content/uploads/2016/12/ENSP-ESCG_ FINAL.pdf. 
2. WHO. WHO report on the global tobacco epidemic 2015 [Internet]. WHO. [cited 2018 Mar 22]. Available from: http://www.who.int/ tobacco/global_report/2015/en/.

3. WHO. Adolescents: Health risks and solutions [Internet]. WHO. [cited 2018 Mar 22]. Available from: http://www.who.int/mediacentre/factsheets/fs345/en/.

4. Hedman L, Andersson M, Stridsman C, Rönmark E. Selection bias in participation in a smoking prevention program among teenagers. European Respiratory Journal. 2014;44(Suppl. 58): P1125.

5. OECD/EU. Health at a Glance: Europe 2018: State of Health in the EU Cycle. Paris: OECD Publishing; 2018 Available from: https://doi.org/10.1787/health_glance_eur-2018-en.

6. Dennis PA, Van Waes C, Gutkind JS, Kellar KJ, Vinson C, Mukhin AG, et al. The biology of tobacco and nicotine: Bench to bedside. Cancer Epidemiology Biomarkers and Prevention. 2005;14(4): 764-767.

7. Benowitz NL, Burbank AD. Cardiovascular toxicity of nicotine: Implications for electronic cigarette use. Trends in Cardiovascular Medicine. 2016;26(6): 515-523.

8. Widysanto A, Saadabadi A. Nicotine addiction. In: StatPearls [Internet]. Treasure Island (FL): StatPearls Publishing; 2019 [cited 2019 May 16]. Available from: http://www.ncbi.nlm.nih.gov/ books/NBK499915/.

9. Tang J, Dani JA. Dopamine enables in vivo synaptic plasticity associated with the addictive drug nicotine. Neuron. 2009;63(5): 673-682.

10. Pidoplichko VI, Noguchi J, Areola OO, Liang Y, Peterson J, Zhang $\mathrm{T}$, et al. Nicotinic cholinergic synaptic mechanisms in the ventral tegmental area contribute to nicotine addiction. Learning Memory. 2004;11(1): 60-69.

11. Zhang $H$, Sulzer D. Frequency-dependent modulation of dopamine release by nicotine. Nature Neuroscience. 2004;7(6): 581-582.

12. Loukola A, Hällfors J, Korhonen T, Kaprio J. Genetics and smoking. Current Addiction Reports. 2014;1(1): 75-82.

13. Yoon D, Kim Y-J, Cui W-Y, van der Vaart A, Cho YS, Lee J-Y, et al. Large-scale genome-wide association study of Asian population reveals genetic factors in FRMD4A and other loci influencing smoking initiation and nicotine dependence. Human Genetics. 2012;131(6): 1009-1021.

14. Han S, Gelernter J, Luo X, Yang B-Z. Meta-analysis of 15 genomewide linkage scans of smoking behavior. Biological Psychiatry. 2010;67(1): 12-19.

15. Role LW, Berg DK. Nicotinic receptors in the development and modulation of CNS synapses. Neuron. 1996;16(6): 1077-1085.

16. Munafò MR, Timofeeva MN, Morris RW, Prieto-Merino D, Sattar N, Brennan P, et al. Association between genetic variants on chromosome 15q25 locus and objective measures of tobacco exposure. Journal of the National Cancer Institute. 2012;104(10): 740-748.

17. Tonstad S, Cowan JL. C-reactive protein as a predictor of disease in smokers and former smokers: A review. International Journal of Clinical Practice. 2009;63(11): 1634-1641.

18. Libby P, Ridker PM, Maseri A. Inflammation and atherosclerosis. Circulation. 2002;105(9): 1135-1143.

19. Ridker PM. Inflammation in atherothrombosis: How to use highsensitivity C-reactive protein (hsCRP) in clinical practice. The American Heart Hospital Journal. 2004;2(4 Suppl. 1): 4-9.

20. van Eeden SF, Yeung A, Quinlam K, Hogg JC. Systemic response to ambient particulate matter: Relevance to chronic obstructive pulmonary disease. Proceedings of the American Thoracic Society. 2005;2(1): 61-67.

21. Todea D, Cosma C, Dicu T, Rosca L, Dinu AC, Risteiu M, et al. Lung cancer risk induced by residential radon in CLUJ and Alba Counties, ROMANIA. Environmental Engineering and Management Journal. 2013;12(6): 1281-1285.

22. Todea D, Cadar O, Simedru D, Roman C, Tanaselia C, Suatean I, et al. Determination of major-to-trace minerals and polyphenols in different apple cultivars. Notulae Botanicae Horti Agrobotanici Cluj-Napoca. 2014;42(2): 523-529.

23. Pappas RS. Toxic elements in tobacco and in cigarette smoke: Inflammation and sensitization. Metallomics. 2011; 3(11): 1181.

24. Vremaroiu-Coman A, Alexescu TG, Negrean V, Milaci MV, Buzoianu DA, Ciumărnean L, Todea DA. Ethical aspects of smoking cessation among the population from Transylvania. Balneo Research Journal. 2018;9(3): 254-259.

25. Thomas JL, Guo H, Carmella SG, Balbo S, Han S, Davis A, et al. Metabolites of a tobacco-specific lung carcinogen in children exposed to secondhand or thirdhand tobacco smoke in their homes. Cancer Epidemiology, Biomarkers and Prevention. 2011;20(6): 1213-1221.

26. Mannino DM, Buist AS. Global burden of COPD: Risk factors, prevalence, and future trends. Lancet. 2007;370(9589): 765-773.

27. Majka DS, Holers VM. Cigarette smoking and the risk of systemic lupus erythematosus and rheumatoid arthritis. Annals of the Rheumatic Diseases. 2006;65(5): 561-563.

28. Lakatos PL, Szamosi T, Lakatos L. Smoking in inflammatory bowel diseases: Good, bad or ugly? World Journal of Gastroenterology. 2007;13(46): 6134-6139.

29. Tonstad S, Cowan JL. C-reactive protein as a predictor of disease in smokers and former smokers: A review: C-reactive protein and smoking cessation. International Journal of Clinical Practice. 2009;63(11): 1634-1641.

30. Budin CE, Marginean C, Bordea IR, Enache LS, Enache EL, Grigorescu $\mathrm{BL}$, et al. The influence of smoking on nicotine 
exposure biomarkers and inflammatory profile among foster care teenagers, Romania. Revista de Chimie (Bucharest). 2018;69(12): 3659-3663.

31. Pepys MB, Hirschfield GM. C-reactive protein: A critical update. Journal of Clinical Investigation. 2003;111(12): 1805-1812.

32. Beelen R, Raaschou-Nielsen O, Stafoggia M, Andersen ZJ, Weinmayr G, Hoffmann B, et al. Effects of long-term expo- sure to air pollution on natural-cause mortality: An analysis of 22 European cohorts within the multicentre ESCAPE project. Lancet. 2014;383(9919): 785-795.

33. Danteș E, Lilios G, Fildan AP. Environmental tobacco smoke exposure - An independent risk factor for lung cancer? Journal of Environmental Protection and Ecology (JEPE), 2014;16(4): 1620-1626. 